\title{
Parading in public: patrician women and sumptuary law in Renaissance Siena
}

\author{
PHILIPPA JACKSON \\ 6 Northampton Park, London N1 2PJ
}

\begin{abstract}
In Renaissance Italy clothing, particularly of women, was strictly regulated; individuals were regularly denounced when walking through the city. Modesty was a virtue in a republican state and dress played a major part in urban identity, reflecting social values and those of the political regime. Sumptuary laws were a major mode of control, particularly of patrician women, whose dress reflected both their own and their family's wealth and status. Despite increased availability of luxurious fabrics encouraged by urban policies, legislation was used to prohibit new forms of dress and raise money for state coffers. At the end of the fifteenth century Pandolfo Petrucci (1452-1512) took control of Siena. The inner elite of his regime, particularly its female members, were given exemptions from the strict legislation and were able to flaunt their elevated status and the new social order.
\end{abstract}

Le Gentildonne Sanesi dovevano far pompa dalla sola modestia. ${ }^{1}$

In February 1452, during the visit of Emperor Frederick III to Siena, Onorata Saracini made a case for simple clothing when reproved by her female companions for her unsuitably plain dress. As the wife of a leading citizen, and member of the wealthy Orsini family, she could have afforded much grander attire but deliberately chose not to make such a public display. Today, clothing in Western European cultures is an individual choice, a mode of self-expression, one in which inappropriate attire may induce at most a raised eyebrow and whispered condemnation. It certainly would not result in court action, a substantial fine and possible damage to the social fabric as occurred in Renaissance Italy. Clothes in early modern Italian cities, both in terms of material and of style, were used to express and reinforce identities, to mark out elites and the differentiation within them. The way in which dress articulated relationships was greatly affected by political circumstances; clothing was a major signifier of both disjunction and change. During the fifteenth century, despite family

1 'Sienese ladies ought to display only their modesty': the words of Onorata Saracini: G. Gigli, Diario Sanese, 2 vols. (Lucca, 1723), vol. I, 51. B. Lapini, Vita di Madonna Onorata scritta da Bernardo Ilicino publicata per la prima volta sopra un codice del secolo XV, ed. G. Vallardi (Milan, 1843). 
competition over religious patronage and the building of chapels in Siena, individuals within the elite supported social cohesion by maintaining control over attire. As the century progressed, however, one community in particular, patrician women, sought to celebrate their exalted status by increasingly grand dress which not only delineated the differences to be found between them and other urban groups but allowed the most important of them to flaunt their social pre-eminence on the urban stage in a way contrary to traditional republican values.

Medieval Siena was a city of fervent religious faith and, like many other Italian states, subject to legislation regulating the display of wealth in public. ${ }^{2}$ Parading in fancy frocks, grand parties, excessive jewellery and the use of gold and silver in clothing were officially discouraged by many statutes which were continually promulgated to deal with changes in fashion and attempts to evade the law. The obsession with regulating clothing in the public arena was common to most Renaissance city-states since dress was the primary means of evoking self-presentation and power; it signalled social and professional standing, political allegiance and wealth. Government time devoted to such legislation in Siena outweighed other provisions on important urban concerns such as hygiene, water supplies, fire precautions and refuse. ${ }^{3}$ The government, in the preambles of sumptuary laws, emphasized a desire to curb wasteful expenditure particularly on 'the superfluous ornamentation of women and their sumptuous dress'; ${ }^{4}$ this was seen as damaging the city and the primary cause of a lack of funds for the payment of dowries. ${ }^{5}$ A woman could not marry without the provision of a dowry, a necessity to promote marriage and maintain population levels, but the need to fund this while ensuring the maintenance of family wealth was a constant social problem. Ecclesiastical condemnation of excess and the sermons of prominent preachers such as St Bernardino of Siena (1380-1444) and Blessed Bernardino of Feltre (1439-94), who both created bonfires of the

${ }^{2}$ E. Casanova, La donna senese del quattrocento nella vita privata (Siena, 1901); C. BonelliGandolfo, 'La legislazione suntuaria negli ultimi anni della Repubblica', Studi senesi, 35 (1920), fasc. 3-4, 243-75, fasc. 5, 334-98; M. Ciatti (ed.), 'Drappi, velluti, taffetà et altre cose': antichi tessuti a Siena e nel suo territorio (Siena, 1994); M.A. Ceppari Ridolfi and P. Turrini, Il mulino delle vanità: lusso e ceremonie nella Siena medievale: con l'edizione dello Statuto del Donnaio (1343) (Siena, 1993); M.A. Ceppari Rifolfi, 'Un caso toscano: Siena', in M.G. Muzzarelli and A. Campanini (eds.), Disciplinare il lusso: la legislazione suntuaria in Italia e in Europa tra Medioevo ed età moderna (Rome, 2003), 59-73.

${ }^{3}$ On urbanism in Siena see F. Nevola, Siena: Constructing the Renaissance City (New Haven and London, 2007); P. Pertici, La città magnificata: interventi edilizi a Siena nel Rinascimento: l'Ufficio dell'ornato (1428-1480) (Siena, 1995).

${ }^{4}$ See the preamble to the law of 22 Jun. 1498 referring to the 'superfluo ornamento delle donne et il loro sumptuoso vestire': Archivio di Stato di Siena (ASS), Balia 253, fols. 45r-47r.

5 ASS, Balia 253, fol. 45r: the expenditure on clothing was the 'precipua causa che nella vostra città non si fa alchuno matrimonio perché le dote che si danno si metteno nel vestire delle donne'. 
vanities in Siena, also criticized female apparel and raised concerns over extravagance and the moral dangers of the pursuit of luxury. ${ }^{6}$

Renaissance dress and display have been the focus of much anthropological and sociological analysis seeking to examine how clothes fashioned an individual and society, and the manner in which component groups articulated their distinctions. ${ }^{7}$ In Siena the most personal way of emphasizing one's social identity was through clothing and patrician women were the most assiduous group within the community to do so, displaying both their own and their family's status. ${ }^{8}$ Although there seems to have been an acceptance of a degree of difference in attire for social classes, excessive extravagance attracted resentment and censure in nominally republican states where corporate values prevailed over individual ones. During the Petrucci domination of the city (1487-1524) the political and social framework of the city altered from a democratic to a more aristocratic model. The chasm between the Petrucci family (with a small band of elite followers) who dominated every aspect of city life and the rest of the population can particularly be charted in the attire of Sienese patrician women. ${ }^{9}$ Politically, there was a constant balancing act between the desire to portray the magnificence expected of leading members of society and traditional republican mores. Government leaders, and by extension their wives, were expected to maintain the honour of their position through their dress, enhancing the republic's status without displaying personal ambition; the dignity of the state was often expressed in ambassadors' outfits revealing that although modesty was the rule at home, grandeur was expected abroad. ${ }^{10}$ On the economic front, the citizens were also involved in the production, importation and exportation of materials: the source of much Renaissance Italian urban wealth was linked to mercantile trade and Siena was no different. The complex relationship of clothing and sumptuary laws to other urban concerns led

${ }^{6}$ On the moral concerns of the church see D.O. Hughes, 'Sumptuary law and social relations', in J. Bossy (ed.), Disputes and Settlements: Law and Human Relations in the West (Cambridge, 1983), 69-99, 79-84; and on Franciscan preaching against luxury M.G. Muzzarelli, "“Contra mundanas vanitates et pompas": aspetti della lotta contra i lussi nell'Italia del XV secolo', Rivista di storia della chiesa in Italia, 40 (1986), 371-90.

7 For the Italian Renaissance see works such as A.R. Jones and P. Stallybrass, Renaissance Clothing and the Materials of Memory (Cambridge, 2000); C. Richardson (ed.), Clothing Culture, 1350-1650 (Aldershot and Burlington, VT, 2004). There is also extensive literature on fabrics and paintings: L. Monnas, Merchants, Princes and Painters. Silk Fabrics in Italian and Northern Paintings 1300-1500 (New Haven and London, 2008); R. Duits, 'Figured riches: the value of gold brocades in fifteenth-century Florentine painting', Journal of the Warburg and Courtauld Institutes, 62 (1999), 60-92.

8 Much research still needs to be done on Sienese Renaissance women: E. Brizio, 'In the shadow of the Campo: Sienese women and their families, c. 1400-1600', in J.G. Sperling and S.K. Wray (eds.), Across the Religious Divide: Women, Property and Law in the Wider Mediterranean ca. 1300-1800 (New York and London, 2010), 122-36.

${ }^{9}$ On Florence see C. Collier Frick, Dressing Renaissance Florence: Families, Fortunes and Fine Clothing (Baltimore and London, 2002).

10 See the government's payment of $£ 481$ for the gold brocade clothing of Giovanni Antonio Saracini, ambassador to the pope, on 4 Jun. 1513: ASS, Balia 61, fol. 32r. 
to the government simultaneously restricting the use of fabrics through sumptuary laws while passing measures to increase trade and commerce in luxury materials.

By the end of the fifteenth century Siena experienced a period of relative political stability and rising wealth from alum, banking and other economic activities. After the return of the Nove faction in 1487, and the rise of Pandolfo Petrucci (1452-1512) and his allies, the political elite formed a tight-knit group with a greater share of city power and wealth allowing them to indulge in their love of material splendour in clothes and public celebrations. The alteration of the political and social landscape of the republic and the increased social differentiation during 1487-1524 can be charted in various ways; in dress this can be seen in government measures over both sumptuary laws and the silk trade and in records of the clothing of Sienese patrician women.

\section{Patrician women and luxury materials}

The city was not always subject to the strict regulation of sumptuary legislation; the laws were completely suspended in Siena for certain celebrations such as the visits of important foreigners whom the city wished to honour with public festivities. ${ }^{11}$ This occurred, for example, during the duke of Calabria's visit in August 1468 but other events might also lead to freedom from the rigid rules. The city magistrates were so delighted to hear of the election of Rodrigo Borgia as Pope Alexander VI (since the Sienese Spannocchi acted as his bankers) that, on 11 August 1492, they declared all sumptuary law restrictions were lifted during that month in celebration. ${ }^{12}$

Sienese patrician women, in particular, were keen to display their wealth and social standing in their attire. ${ }^{13}$ As early as December 1291 some of them petitioned the new podestà, Count Robert of Arras, to ask the government to lift the restrictions on crowns and silver and gold garlands set with pearls and jewels. ${ }^{14}$ By the fifteenth century any woman who possessed a silk dress had to present it for marking and approval to the authorities who made detailed notes of the colour, types of sleeves, linings and other decorative details which were all subject to various degrees of regulation. The taste for elegant apparel can be seen by the descriptions of

${ }^{11}$ For a summary of the visits of foreign royalty of the latter half of the fifteenth century: P. Piccolomini, Dalla vita e dalla poesia curiale di Siena nel Rinascimento. Nozze Piccolomini-Ciacci (Siena, 1904), and on public festivities: A. Provedi, Relazione delle pubbliche feste negli ultimi cinque secoli (Siena, 1791).

12 ASS, Balia 37, fol. 47r-v.

${ }^{13}$ Italian women were considered to be the prime exhibitors of their husbands' and fathers' status: M.G. Muzzarelli, 'Una società nello specchio della legislazione suntuaria: il caso dell'Emilia-Romagna', in Muzzarelli and Campanini (eds.). Disciplinare il lusso, 17-31 (24).

14 C. Kovesi Killerby, Sumptuary Law in Italy 1200-1500 (Oxford, 2002), 121. For early jewellery ownership see L. Zdekauer, 'I gioelli d'una gentildonna senese del dugento (1272)', Bullettino Senese di Storia Patria, 6 (1899), 520-3. 
various gowns presented to the authorities for marking in 1413 and others, which included outfits of velvet and brocade made with silver and gold, which were recorded following the luxury tax of February $1422 .{ }^{15}$ The cost of these materials could be immense and a severe drain on family resources, however, particularly by the early sixteenth century when grander clothes were increasingly worn. Camillo Petrucci, Pandolfo Petrucci's brother, was a successful silk merchant whose son Francesco married into the eminent Piccolomini family. He made a special proviso in a testament of 1511 that all the materials removed from his shop to make his daughter-in-law's dresses be fully charged to Francesco, implying that the cost was so great that it should not be borne by his other heirs. ${ }^{16}$

The question of both the application of Sienese sumptuary laws and prosecutions for breach is difficult to assess due to the destruction of many relevant records yet the laws themselves, inventories and court cases do indicate contemporary attitudes. Sumptuary legislation often did not apply to a number of the leading members of society who included knights, men with particularly high incomes (and their wives) and foreigners attending the university. ${ }^{17}$ There were also specific exemptions for citizens acting on official business as a member of the government or as an ambassador since such finery was equated to the city's honour. ${ }^{18}$ The laws were so many and so complex, however, that inadvertent breaches could occur. Giorgio Sensi was condemned for wearing a silver brocade doublet, for the entrance to Siena of the duchess of Ferrara on 18 June 1473. His father-in-law gave evidence that Giorgio was chosen as an official to accompany the duchess and so believed he was exempt from regular sumptuary law provisions. ${ }^{19}$

A specific licence to wear what one wished was the simplest way to avoid such prosecutions but this was very rare in Siena. One notable case was that of Battista Berti, wife of Achille Petrucci, the most famous of the educated young women who traditionally made Latin orations to welcome

${ }^{15}$ For the 1413 records see Casanova, La donna senese, 74-6: the name and residence of the owner was noted together with details of the gowns e.g. 'Uxor Antonii Bartolomei Vannis Cini, populi Sancti Martini habet unum vestire velluti nigri figurati cum manicis apertis cum frappis argentatis.' For 1422 see S. Paghi and C. Palazzuoli, 'Cittadini e preziosi vestimenti 1422', in M. Ascheri and D. Ciampoli (ed.), Siena e il suo territorio nel Rinascimento (Siena, 1990), 99-119.

16 The will of Camillo Petrucci of 16 Apr. 1511 contains the provision: 'Tucti li drappi che dicto Francesco ha levato dala buttiga dell'arte dela seta per vestire la moglie s'intendino essere a debito di dicto Francesco': ASS, Notarile Ante-Cosimiano 1001, doc. 2944.

17 See, for example, the law on funeral attire of corpses, 'de vestibus defunctorum', in the statute of 1343 which declared that counts, soldiers, judges, doctors (both medical and of other faculties) and their wives were not subject to its provisions: 'exceptis tamen comitibus, militibus, iudicibus, medicis fisicis et doctoribus cuiuscunque facultatis et eorum et cuiusque eorum uxoribus': Casanova, La donna senese, 55.

18 The 16 Mar. 1502 law against silk clothing for men under the age of 30 was not to apply to: 'cavalieri, doctori o chi fusse in magistrato de Magnifici Signori Gonfalonieri Maestri o chi fusse mandato o Ambasciadore o Commissario': ASS, Balia 253, fol. 152v.

19 Casanova, La donna senese, 45. 
important visitors to the city. Her eloquence before Emperor Frederick III in February 1452 was such that the emperor offered her anything she wished; Battista chose exemption from sumptuary laws as her reward, a visual testament to her intellectual gifts. ${ }^{20}$

A woman flaunted her status by parading through the city's streets. This was where she was seen by her fellow citizens and where she also risked being denounced for her clothing; the most likely time for a woman to be so observed was when walking to attend mass. ${ }^{21}$ Under a law of 28 August 1433, a woman stopped in public for breach of sumptuary legislation was obliged not only to give her own name but those of her father and husband and place of residence so that further disciplinary action could be taken. ${ }^{22}$ Denunciations by members of the public were encouraged and could be made verbally, or in writing. In the early sixteenth century there was a small box set out near the door entering into the magistracy of the Regolatori into which written complaints could be placed and also another box for reports in the cathedral. ${ }^{23}$

The surveillance of fellow citizens and reporting of those who stepped out of line was an integral part of the way in which fifteenth-century Sienese society sought to maintain social cohesion. On 10 April 1476, Messer Lorenzo di Messer Antonio Lanti had to justify to the Tre Segreti, the magistrates in charge of the implementation of sumptuary law, why his wife had twice during the previous month paraded in a dress of silk velvet in public. ${ }^{24}$ In Siena, certain luxury clothes could only be worn by citizens and their wives who were recorded in the state tax records, the Lira, as being over a specified tax rating. Lorenzo's defence was that although he did not have the required rating under Sienese law for his wife to wear such apparel, he knew that knights and their wives were specifically exempt from sumptuary law legislation: he explained that his father Antonio, councillor to Francesco Sforza, duke of Milan, and an ambassador to the king of Cyprus, had received knighthoods for himself and his two sons. Although Lorenzo Lanti was convicted for his wife's behaviour at the first instance he won his case on appeal as the court found that he was a knight and so not subject to the law. Thus although the jealousy of other Sienese citizens may have led to Lorenzo's wife being denounced, the courts recognized that both he and his spouse were legally entitled to dress as they wished.

${ }^{20}$ Gigli, Diario Sanese, vol. I, 51-2; O. Malavolti, Historia del Sig. Orlando Malavolti, de' fatti, e guerre de' Sanesi, cosi esterne, come civili (Venice, 1599), Book 2, Part 3, 38.

${ }^{21}$ Minoccia di Ranierio was prosecuted for wearing a dress with an over lengthy train when she attended mass at San Francesco in 1473: Casanova, La donna senese, 40 (n. 4).

22 Casanova, La donna senese, doc. VII, 84-8, at 86.

23 ASS, Balia 253, fol. 47r, 22 Jun. 1498: 'alla porta delli Regolatori stia una cassetta a dicto effecto ed un'altra in Domo alla colonna riscontra al'altare del Crocefisso nelle quali si mettino le politie e petitioni ... le quali cassette si debbino aprire ogni mese per il notaro di Balia'.

${ }^{24}$ Casanova, La donna senese, 50 (n. 1); Kovesi Killerby, Sumptuary Law, 157. 
Although there was wider acceptance of luxury materials during the early sixteenth century there were also detailed provisions on enforcement of breaches of the law with renewed registrations of silk dresses in 1498 and restrictions on the use of gold and silver in fabrics. ${ }^{25}$ During the fifteenth century if someone was seen in public wearing a particular outfit the alleged culprit could not be condemned unless at least two trustworthy witnesses were willing to attest to this. Due to the problems of prosecuting effectively, a law of 1502 provided that the denouncer's name should remain secret, and the officials in charge of sumptuary law petitioned the government to be allowed to make decisions on breach without calling any witnesses, stating that it was hard to find people willing to give evidence. ${ }^{26}$ The Petrucci control of the state led to a climate of fear and certain eminent citizens behaved as if they were above the law. Sumptuary legislation became stricter for all except the leading members of society and there were even detailed regulations on children's clothing so that, for example, boys under the age of 15 years could wear silk doublets only if they had a tax rating of 1,000 lire or more. ${ }^{27}$

\section{Promotion of the silk trade}

In the early sixteenth century extensive measures protected the producers and merchants of luxury goods, who were members of the governing elite; an oration in praise of the silk trade named a long list of distinguished Sienese families, 40 in number, including the Piccolomini, Petrucci, Chigi, Borghesi and Spannocchi. ${ }^{28}$ These businessmen were highly successful and silk shops were found primarily in the smartest areas of the city, particularly along the Strada Romana. ${ }^{29}$ The business interests of the city's clothiers were a hallmark of urban policy during this period.

In 1489, the government wrote to Sultan Bajazet II to request permission to establish a permanent Sienese consulate in Constantinople, which would place their merchants on the same basis as those of Venice, Florence, Ragusa and Ancona. ${ }^{30}$ The attempt appears to have failed and the government

25 See the 1498 law: ASS, Balia 253, fols. 45r-47v.

26 For the 1502 law see ASS Balia 253, fols. 152r-154v, and for the undated petition: ASS, Concistoro 2193.

27 ASS, Balia 253, fols. 360v-361r, 'Item li maschi da anni xv in giù se non sonno allirati $£ 1000$ o da inde in su non possino portare giubbone di seta di alcuna sorte.'

28 The undated oration is to be found in ASS, Notarile Ante-Cosimiano 1447; other important Sienese families named include the Pecci, Ugurgieri, Agazzari, Tolomei and Boninsegni.

29 On the Strada Romana see F.J.D. Nevola, "Ornato della città": Siena's Strada Romana and fifteenth-century urban renewal', Art Bulletin, 82 (2000), 25-50; idem, "'Più honorati et suntuosi ala Republica": Botteghe and luxury retail along Siena's Strada Romana', in B. Blondé et al. (eds.), Buyers and Sellers: Retail Circuits and Practices in Medieval and Early Modern Europe (Turnhout, 2006), 65-78.

30 ASS, Concistoro 1701, fols. 65v-66r, 11 Aug. 1489. The letter recommended Niccolò of Montepiscali, a Sienese resident of Constantinople, as consul. 
later asked the Florentines for help; Andrea Carnesecchi, the Florentine representative in Constantinople, was requested to take Sienese merchants under his protection in 1501. ${ }^{31}$ In March 1497, the government gave tax exemptions in relation to the cloth trade in the Levant and continued to encourage the export of fabrics. ${ }^{32}$ It appointed, on 25 June 1506, Pandolfo Petrucci and two colleagues, to oversee the silk trade and in July gave them power to grant privileges and immunities. ${ }^{33}$ In September, they gave local merchants a twelve-year immunity from payment of the gabelle tax for exporting material and a five-year exemption for importing unboiled silk. ${ }^{34}$ The encouragement of international trade ran in tandem with local protectionism whereby the government sought to prevent foreign fabrics entering the city. ${ }^{35}$ The Petrucci regime's most important action in this area, however, was the reform of the statute governing the silk industry in 1513, which primarily covered questions of management, taxation and punishment for contravention of its rules. ${ }^{36}$

\section{Siena under the Petrucci: magnificent clothing and public display}

By the early sixteenth century there was far tighter legislation over breaches of sumptuary law along with a greater availability of luxury fabrics. The greater restrictions on the majority of citizens, who were penalized heavily for contraventions, went hand in hand with far more magnificent dress for the inner elite of the Petrucci regime, who gained increasing exemptions from the harsh new laws and publicly flaunted their wealth. This created social tension and resentment. The number of sumptuary laws passed also reveal details of the fast-changing nature of Renaissance fashions and their timing shows the close correlation in Siena between the financial state of the government and the use of such legislation as a tax-raising measure. ${ }^{37}$ The law of 22 June 1498 directed mainly at patrician women was passed when

31 On the protection of Sienese merchants in the Orient by the Florentines see the letter of 27 Dec. 1501 in G. Müller, Documenti sulle relazioni delle città toscane coll'oriente cristiano e coi Turchi fino all'anno MDXXXI (Florence, 1879), 250-1, at 251, reporting that the Sienese ambassador had said certain of their merchants wanted 'accompagnare con la natione nostra, acciò che vivino costà et travaglino le loro mercantie con tucte quelle sicurtà et privilegii che havete voi'.

32 ASS Balia 253, fol. 18v, 'considerato di quanta utilità commodo et honore sia alla nostra ciptà questo traffico di vendere panni in Levante'.

33 ASS, Balia 52, fols. 60v and 69r. The three appointed were Pandolfo Petrucci, Agnolo Palmieri and Iacobo Venturi. See G.A. Pecci. Memorie storico-critiche della città di Siena, 2 vols. (Siena, 1755, repr. Siena, 1988), vol. I, part 1, 221.

34 ASS, Balia 253, fol. 229r-v, 7 Sep. 1506.

35 ASS, Balia 47 , fols. $138 \mathrm{v}-139 \mathrm{r}$.

${ }^{36}$ On the silk industry in Siena see L. Banchi (ed.), L'arte della seta in Siena nei secoli XV e XVI: statuti e documenti (Siena, 1881); L. Molà, The Silk Industry of Renaissance Venice (Baltimore and London, 2000), 9-10, 33, 45 and 180-1; S. Borghesi and L. Banchi, Nuovi documenti per la storia dell'arte senese (Siena, 1898), 120-1, 122-3, 126-7, 128-30, 146-7, 152-3.

37 The Sienese evidence backs the thesis of Jane Bridgeman who argues that the wealthy paid for the privilege of indulging in fine clothing: J. Bridgeman, "Pagare le pompe": 
the government needed funds for the state bank; it dealt with jewellery, silk and the use of metal decorative details on clothing. ${ }^{38}$ One provision specified that the production of materials containing gold and silver was banned, except of those used for religious purposes, and the clause was specifically applied at home as well as in public. ${ }^{39}$ On 16 March 1502, proposals were put forward for restrictions on the types of clothes, sleeves and trains women could wear, the number and value of jewels (whether false or not), and the wearing of silk by boys and young men under the age of $30 .{ }^{40}$ The provisions were passed with certain modifications such as allowing women a number of hair ornaments. ${ }^{41}$ In January 1506, when the regime was more secure, the laws were relaxed to a certain extent with a provision allowing women to wear two silk garments simultaneously. ${ }^{42}$

The stronger oligarchical control in the city can be seen in specific exemptions from sumptuary legislation for leading members of society. This had been rare in republican Siena although certain Piccolomini were given special privileges during the fifteenth century due to their relationship with Pope Pius II. ${ }^{43}$ Pandolfo Petrucci, Siena's leading figure, was modest in his dress and demeanour, wearing black and maintaining the fiction of being a simple citizen. The government allowed minor exemptions in the early sixteenth century to certain female members of his family, which led to a much wider freedom of dress for the Petrucci following Pandolfo's death. The first example of this favouritism occurred on 11 July 1505 when two of his daughters, Sulpitia and Girolama, were given exemptions, and a similar licence was granted to Camilla, daughter of another leading government figure, Agnolo Palmieri, the following week. ${ }^{44}$ Privileges often seem to be related to foreign brides and to the celebration of marriages when families wished to display their social preeminence, as in the case of Violante Farnese who was given a special 20-day exemption following her arrival in Siena to marry Gaspare Petrucci

why quattrocento sumptuary laws did not work', in L. Panizza (ed.), Women in Italian Renaissance Culture and Society (Oxford, 2000), 209-26.

38 ASS, Balia 253, fols. $45 \mathrm{r}-47 \mathrm{v}$.

39 ASS, Balia 253, fols. 45v-46r: 'non si possi mettere in alchuno lavoro di panni lini oro, o argento filato, o tirato fino, o falso excepto pero quelle cose che si facessero per operare al culto divino et paramenti et ornamenti di chiesa'.

40 ASS, Balia 253, fols. 152r-154v.

41 ASS, Balia 253, fols. 154v-155r, 10 Apr. 1502.

42 ASS, Balia 253, fol. 215r, 16 Jan. 1505 (modern dating 1506), 'due vestes siricee uno et eodem tempore possint ferri'.

43 The sumptuary laws of 11-26 Oct. 1460 did not apply to the nieces, nephews and cousins of Pius II, nor to certain members of his household: Casanova, La donna senese, doc. IX, 91-5 'et tali provisioni non s'intendino per le nipoti carnali et cugine carnali et per le donne de' nipoti carnali et per le donne de thesaurieri, depositarii et secretarii di papa Pio secondo senese che fussero continui commensali in casa del Papa'.

44 They were allowed to wear 'vestes muffati' ASS, Balia 51, fol. 42r; ASS, Balia 253, fol. 47r, contains the punishment for derogation of the sumptuary law to try to prevent future suspension or exemption; for Camilla's licence see ASS, Balia 51, fol. 45r. 
in $1499 .{ }^{45}$ Pandolfo's eldest daughter, Sulpitia, was specifically permitted to wear pearls and diamonds, on 25 February 1508, for her wedding to the banker, Sigismondo Chigi, which took place in Lent, a period in which modesty and restraint was required by religious custom. ${ }^{46}$ It was not only Petrucci women who were granted such special status since sumptuary law exemption was granted to the wives of Pierfrancesco and of Alessandro Piccolomini in May 1509 and to all daughters and daughters-in-law of Pandolfo on 14 September $1509 .{ }^{47}$ The reason for the latter was that the Petrucci family wished to hold a particularly grand ceremony for that month's wedding of Pandolfo's son and main heir, Borghese, to Vittoria Piccolomini, niece of Pope Pius III. ${ }^{48}$ The special status of these two families was confirmed after the death of Pandolfo when, in a new sumptuary law of 22 January 1513, the provisions were specifically declared not to apply to the sons, daughters and daughtersin-law of Pandolfo Petrucci, nor to the wives of Pierfrancesco, Silvio and Alessandro Piccolomini. ${ }^{49}$

It was not only patrician women whose clothes attested to the elite's control of the city, although they were the most prominent group. During the first decades of the sixteenth century, government leaders used clothing as one of the most public ways in which to emphasize their position, relaxing republican conventions to demonstrate their superiority over a local audience. The importance of wearing grand clothes in public can be seen in Sienese letters and in the correspondence of a Florentine ambassador, Andrea da Foiano, who sought a new cloak with velvet edging while residing in Siena in $1490 .^{50}$ Antonio Bibbiena in a letter to the ambassador implied that such clothing would not be acceptable in Florence. Literature also attests to extravagant tastes in Siena, particularly a 1506 poem about the Assumption celebrations in the city which refers to the elaborate materials worn by the participants and the oriental fabrics for sale in the city's streets. ${ }^{51}$ The period 1487-1524 was also one of sumptuous wedding celebrations and public display such as the triumphal arches at the Spannocchi marriages of 1494, and on 23 January 1509, the laws relating to restrictive numbers at wedding receptions were relaxed so that spouses

45 ASS, Balia 45, fol. 25r.

46 For Sulpitia's exemption, specifically referring to precious diamonds and pearls 'pretiosas margaritas et perlas': ASS, Balia 53, fol. 154r, 25 Feb. 1507 (1508 in modern dating).

47 ASS, Balia 55, fols. $24 \mathrm{v}$ and $57 \mathrm{r}$.

48 The private ceremony in front of the notary took place on 9 Sep.1509 but the religious (and public) one occurred on 23 Sep.: S. Tizio, Historiarum Senensium, Biblioteca Comunale di Siena, Ms.B.III.12, 152.

49 See ASS, Balia 59, fol. 58v, when the new laws were declared not to apply to the 'filii filie et nuris olim felice recordo magnifici Pandolfi de Petrucciis et uxores D. Petri Francesci D. Silvii et Domini Alexandri de Piccolhominibus praesertim quia sunt forenses'.

50 See A. Brown, 'Lorenzo de'Medici's new men and their mores: the changing lifestyle of quattrocento Florence', Renaissance Studies, 16/2 (2002), 113-42, 125-6.

51 G. Catoni and A. Leoncini, Cacce e tatuaggi. Nuovi ragguagli sulle contrade di Siena (Siena, 1993). 
could invite more relatives and friends to the festivities. ${ }^{52}$ This was another move away from the modest restraint traditionally required of republican citizens. The number of luxury materials owned is also reflected in the domestic inventories of the elite which contain many items of a costly nature, whether for personal wear or in bedhangings. ${ }^{53}$ Female garments were exceedingly elaborate and expensive particularly those made of silk, velvet or brocade: Ippolito Bellarmati left 70 florins to pay for his niece's wedding dress in a testament of 10 September $1498 .{ }^{54}$ Cristofora di Camillo Petrucci, widow of Iacobo Bichi and daughter of a silk merchant, listed the value of certain possessions which included three silk dresses worth 100 ducats in $1529 .{ }^{55}$ Francesca Turamini, wife of Giovanfrancesco Petrucci, owned a large number of grand outfits in 1509 including two gowns, one of green velvet and one of yellow taffeta, both with silver fastenings, and a cloak of black velvet lined with green silk damask. ${ }^{56}$ Public parading in such attire by these women indicated the social and political transformation of Sienese society to the city's residents and foreign visitors.

Fine clothing and ceremonial display had long been a vital aspect of city life in Renaissance Siena which helped confer honour on the state: luxury materials were traditionally used to create a corporate identity and constituted an essential element of ritual urban events. There were strict rules on personal attire, however, particularly of patrician women; a republic ideally comprised a community of modest citizens. As Sienese society became less equal at the end of the fifteenth century, the change was particularly reflected in clothing paraded through the city's streets. Dress increasingly became a signifier of individual rather than corporate status and that of patrician women attested to the power of the ruling elite who gained special exemptions from the law and ignored republican mores. This community represented a social identity to match the new Renaissance taste in palace construction, decoration and public celebrations. The Sienese desire for luxury clothing was such that it was even lampooned by Niccolò Machiavelli in his poem De Ambitione referring to the 1509 duel of Pandolfo Petrucci's sons over the wedding

52 ASS, Balia 253, fol. 270v.

53 Many of these remain unpublished but see C. Mazzi, La casa di maestro Bartolo di Tura (Siena, 1900); L.G. Pélissier, 'Le trousseau d'un siennois', Bullettino Senese di Storia Patria, 6 (1899), 147-50. The bed of Raimondo Tolomei, specifically bequested to his wife in his will of 13 Jan. 1523 was valued at 50 florins: 'una lectiera alla chuccia con uno lecto di piuma et fornimenti convenienti': ASS, Notarile Ante-Cosimiano 817, doc. 437.

54 ASS, Notarile Ante-Cosimiano 569, 41.

55 ASS Rota, 113, 26 Jan. 1528(9).

56 ASS, Notarile Ante-Cosimiano, 1290, 21 Dec. 1509: 'una cotta di velluto verde con affibiatura d'argento grande', 'una cotta di taffeta giallo con affibiatura d'argento', 'una sbernia di velluto nero foderata di damascho verde'. 
gifts of clothes presented by their brother-in-law, Chiappino Vitelli. ${ }^{57}$ When the last Petrucci government fell in 1524 a new political regime tending towards sobriety took power which passed the severe sumptuary law in February 1526 marking the return to stricter modesty. ${ }^{58}$ The Petrucci period of conspicuous consumption, grand outfits, public ostentation and the flaunting of wealth by patrician women in the city's squares and streets was over.

57 O. Tommasini, La vita e gli scritti di Niccolò Machiavelli nella loro relazione col Machiavellismo, 3 vols. (Turin 1883-1911; repr. Bologna 1994-2003), vol. I, 536; Tizio, Historiarum Senensium, 57; Pecci, Memorie storico-critiche, vol. I, part 1, 242.

58 ASS, Consiglio Generale 242, fols. 78v-82r. 